\title{
CHANGES IN RODENT COMMUNITIES AS CONSEQUENCE OF URBANIZATION AND INAPPROPRIATE WASTE MANAGEMENT
}

\author{
BUZAN, E. ${ }^{*}$ - ZuPAN, S. - JUGOVIC, J. \\ Department of Biodiversity, Faculty of Mathematics, Natural Sciences and Information \\ Technologies, University of Primorska, Glagoljaška 8, 6000 Koper, Slovenia \\ Institute for Biodiversity Studies, Science and Research Centre, University of Primorska, \\ Garibaldijeva 1, 6000 Koper, Slovenia \\ e-mail: sara.zupan@upr.si; jure.jugovic@upr.si \\ *Corresponding author \\ e-mail: elena.buzan@upr.si; tel: + 38-65-611-7662; fax: +38-65-663-7710 \\ (Received $3^{\text {rd }}$ Sep 2016; accepted $15^{\text {th }}$ Dec 2016)
}

\begin{abstract}
One of the unpleasant byproducts of urban living is municipal solid waste. Unfortunately, many urban areas cannot effectively manage their waste, which causes creation of illegal waste sites. We investigated communities of small mammals from 14 illegal waste sites in Mediterranean Slovenia and Croatia. Five species of the family Muridae were recorded: black rat (Rattus rattus), domestic mouse (Mus musculus), wood mouse (Apodemus sylvaticus), striped field mouse (Apodemus agrarius), and yellow-necked mouse (Apodemus flavicollis). Black rats and house mice, the two commensal species, were exclusively found or prevalent in larger waste sites, while the other three Apodemus species were most frequent in natural or seminatural habitats (> $90 \%$ specimens). At large waste sites and in the human settlements, commensal species evidently outnumber the three native Apodemus species $(<25 \%$ of specimens). Our results show that improper waste management drives the native rodents to local extinction and replacing them with invasive commensal species, thereby reducing biodiversity and ecosystem health. We conclude that higher rates of parasitism and infestation with different pathogens in waste sites, especially those in the close proximity of human settlements can raise the possibility of transferring the pathogens and parasites either to the people or their predators.

Keywords: urban ecology, biodiversity treats, Mediterranean coast, anthropogenic influence, solid waste management
\end{abstract}

\section{Introduction}

Among many anthropogenic pressures worldwide, urbanization is one of the most rapidly increasing threats on natural habitats, causing both biodiversity loss and biological homogenization (McKinney, 2002; Savard et al., 2000). By the year 2025, about $61 \%$ of the world's population is predicted to be living in urban areas, especially in developing countries (UNDESA, Population Division. World Urbanisation Prospects: The 2009 Revision, 2010). The expansion of urban areas into natural habitats causes significant changes in species compositions, species interactions, and also impacts ecological and evolutionary processes (Aronson et al., 2014; McKinney, 2008). Urban ecosystems lower the quality of ecological services, with limited capacity to prevent pest outbreaks (Morello et al., 2000).

The Mediterranean coast is a densely populated region with an intricate political history involving many different ethnic groups. Slovenia and Croatia are two, among 21 countries, that have coastlines on the Mediterranean Sea. In both countries high population density and economic activities near the coasts cause significant pressures on coastal areas and their landscapes in particular. As the coastal population grows and 
urbanises its environment, natural coastal habitats and landscapes get further fragmented. The land use changes with the corresponding change in the landscapes leading to decreasing integrity of coastal landscapes and ecosystems (UNEP/MAP: State of the Mediterranean Marine and Coastal Environment, 2012).

In addition to higher human population density, changes that occur along urban-rural gradients (McDonnell and Pickett, 1990), include the loss of biota and natural habitat, increased densities of roads, buildings and other surfaces, and microclimatic shifts (e.g. heat island effects) (Bradley and Altizer, 2007). Although the conversion of natural or semi-natural to urban ecosystems can be a slow process, it is usually irreversible (Morello et al., 2000; Power, 2010).

The rapid development of urban ecosystems generates waste, and landfills are the most frequent waste disposal method worldwide. The growth in waste has led to serious management problems in various cities and countries (Rodríguez et al., 2007). Despite the policies of reduction, reuse, and diversion away from the use of landfills, more than half of the European Union (EU) member states still direct more than $75 \%$ of their solid waste to landfills (Mazzanti and Zoboli, 2008). The structure of urban areas and their outskirts consist of a variety of components, ranging from completely built environments to natural or semi-natural areas (McDonnell and Pickett 1990), the latter often used for the uncontrolled waste disposal. These sites affect biodiversity, ecosystem and human health, by facilitating the spread of invasive species, disease vectors, pathogens, and pollution (Vrijheid, 2000).

Solid waste management is one of the major public health and environmental concern in the EU. The public sector is unable to deliver services effectively, regulation of the private sector is limited, and illegal dumping of domestic and industrial waste is still a common practice (Reddy and Chirakkara, 2013). Despite the strong activity of European Union towards improving waste management policies, there is still a considerable amount of illegal waste dumping, and more than 7,000 dumping sites identified as 'the tip of the iceberg' (Giusti, 2009). Illegal waste sites are a fast growing problem in many European countries (Council Directive 1999/31/EC on the landfill of waste, 1999). Despite the existing infrastructure for dealing with waste, studies revealed an extensive network of illegal waste sites (Mazzanti and Zoboli, 2008).

These sites provide a ready source of nutrition and shelter for human-introduced species that support the spread of pathogen vectors and non-native/invasive species (Rusterholz et al., 2012), while discarded pollutants can disperse across the landscape (Diletti et al., 2008; Mattiello et al., 2013). As a consequence, illegal waste sites pose serious economic and social challenges through an increased burden upon the public health system (Ashworth et al., 2014; Elliott et al., 2001; Minichilli et al., 2005; Porta et al., 2009), and may lead to declines in ecosystem functions (Ettler et al., 2008; Kotovicova et al., 2011).

Many publications refer to the influence of specific chemicals or chemical mixtures in illegal landfills on human health (Baibergenova et al., 2003; Kramer, 1987; Sorsa et al., 1992; Sullivan, 1993) but there are almost no data about their influence on biotic homogenisation and the spread of pathogens throughout the rodents living area. It has been recently highlighted that urbanization is a major cause of biotic homogenization (McKinney, 2006; Smart et al., 2006) and that it usually leads to higher prevalence of alien animal and plant species (McDonnell et al., 1997; Melles et al., 2003). For example, garden waste deposited in semi-natural and natural habitats, such as forests, could be a source of dispersion for non-native plant species (Rusterholz et al., 2012). 
Some of these species have a high regeneration potential and may successfully colonize forests (Klimesová and Klimeš, 2007).

To predict the impact of urbanisation processes upon biodiversity and human wellbeing, it is crucial to understand the shifts in species composition and diversity (Desrochers et al., 2011). For instance, changes in landscape structure, such as an increase in urban patches with increased number and size of waste sites, alter the ability of some commensal organisms to disperse. In such a case, communities composed of species with specific habitat requirements have higher local extinction and turnover rates, whereas widespread and broadly tolerant species benefit from landscape disturbance and demonstrate higher stability (Dall and Cuthill, 1997; Krauss et al., 2004).

The Mediterranean coast, including both Slovenia and Croatia, is a densely populated region in EU where most of the population growth takes place in a dispersed small and medium-sized towns and cities (Cori, 1999; "UNEP/MAP/BP/RAC. A sustainable future for the Mediterranean," 2005) usually without adequate waste management (Ballantyne and Pickering, 2015).

An extensive network of urban landscape and natural habitat dissects the Istrian peninsula shared between Slovenia and Croatia (Kokalj and Oštir, 2005). Medium-sized towns are located on the coast and oriented towards tourism that considerably increase human concentration and waste production. An additional source for waste sites is created by small towns, villages, and small farms that are mainly are dispersed in the central part of peninsula (Gržinić, 2010). Study done on two small rodents species showed that road clearance without vegetation is an inhibiting factor for crossing the road (Macpherson et al. 2011). So, even the small roads, with relative little traffic, do act as a partial barrier for small mammals, reducing their movements between habitats on either side of the road.

There is little information on the effect of uncontrolled waste sites dispersal on rodent communities (Cavia et al., 2009). Rodents are attracted by solid and decomposing organic waste discarded at illegal waste sites. Data on rodent distribution in urban and semi-natural ecosystems is important, as these animals can cause damage to stored food, buildings, and infrastructure (Battersby, 2004; Drummond, 2001). Moreover, rodents are known to be involved in the transmission of diseases to humans and domestic animals (Battersby and Greenwood, 2004). They are a notorious reservoir for a number of pathogens and can act as either principal infected hosts or hosts for arthropod vectors (Desjeux, 2001). Rodent-borne zoonosis, transmitted from rodent to human hosts, can cause significant human morbidity and mortality globally, with thousands of cases diagnosed in Europe annually (Semenza and Menne, 2009).

Until now, no study has specifically investigated the distribution of rodents within the urban and semi natural-environment in relation to uncontrolled waste dumping. The aim of this study was to assess the potential effects of illegal waste dumping on the establishment of rural-like versus truly commensal rodent communities in semi-natural habitats. In particular, we looked at the spatial species turnover rates as a function of urbanisation and presence of illegal waste sites. Finally, we studied the effects of landscape structure on the composition of rodent communities. The higher parasitism and infection rates (Bužan et al., 2012) of animals in illegal waste sites could be significantly associated with the change in the rodents communities. Rodents at these sites are either more exposed or more susceptible to parasites or infections, which could have a possible negative impact upon their predators and people. Higher parasitism and infection rates can 
therefore be used as a measurable impact of changed rodent community that further impacts on their predators and people living nearby the waste sites.

We conducted our study in the coastal areas of Slovenia and Croatia, as they represent areas where urbanisation increases pressure on natural resources during limited time periods, and leads to higher rates of sewage and solid waste production.

\section{Materials and Methods}

\section{Study area}

Fieldwork was conducted in Istria, a peninsula in the Northern Adriatic, shared by Italy, Slovenia, Croatia, and in the Brijuni Archipelago located at the western shore of Istria with an area size of $3,160 \mathrm{~km}^{2}$. According to the geological and geomorphic structure, the peninsula can be divided in three different areas (Sombke and Schlegel, 2007). The hilly northern and north-eastern part of the peninsula is characterised by scarce vegetation and bare karst surfaces. The south-west region is characterised by lower flysch mountainous tracts consisting mainly of impermeable marl, clay, and sandstone. Finally, the last part is the limestone terrace along the coastline covered with red earth (Krebs, 1907).

One third of the Istrian peninsula is covered by forest. Pinewoods, maquis, holm oak (Quercus ilex), and strawberry tree (Arbutus unedo) prevail along the coast and on the islands. The present grasslands are among the species-richest habitats of Europe and maintain high small-scale densities of plant species (Kaligarič et al., 2006). They are of semi-natural origin, as they have emerged through centuries or millennia of lowintensity land use (Bohn et al., 2004; Ellenberg and Leuschner, 2010). During the $20^{\text {th }}$ century, the original grasslands were replaced by agro-systems, which are nowadays continuously being replaced by urban habitats. Today, the area represents a matrix of mixed urban, agricultural, and fragmented natural or semi-natural vegetation patches.

The sampling sites differed significantly according to the anthropogenic impact, and three groups of sites were immediately identified (Figure 1, Table 1): group A: natural habitats with low anthropogenic impact; group B: habitats with medium anthropogenic impact; and group C: habitats with high anthropogenic impact with large waste sites and/or human settlements.

\section{Field data collection}

Sites for data collection were located in illegal waste sites in groups A-C. In total, 17 areas (Figure 1) were sampled in the warmer part of the year (from April to November) between October 2011 and November 2012. Sherman traps of two sizes (dimensions of small Sherman traps: 50.08 × $6.35 \times 22.86 \mathrm{~cm}$; and dimensions of large Sherman traps: $7.62 \times 8.89 \times 22.86 \mathrm{~cm}$ ) in equal shares were used. Sardines with breadcrumbs or peanut butter were used as bait. Traps were set in late afternoon/evening and rodents were sampled overnight. After each sampling night, traps were checked; trapped animals were euthanized in $\mathrm{CO}_{2}$ chamber, and immediately transported to the laboratory. In one location traps were set 1-18 times (mean $\pm \mathrm{SD}=4.94 \pm 4.41$ ) with 20-80 traps (mean \pm $\mathrm{SD}=52 \pm 20.8$ ). The number of traps was defined by the size of the sampling area. Sampling areas differed considerably in habitat characteristics and level of anthropogenic impact (see Figure 1, Table 1). Three of the sampling locations on the 
Brijuni islands (Figure 1) were excluded from further analysis, as only the introduced black rat (Rattus rattus) was present on these islands.

Table 1. The summary data on sampling sites in Istria. Each of the sampling site was assigned to one of five habitat types $\left({ }^{1-5}\right)$, data are presented in proportions to total investigated area). A1-A4 = natural habitats with low anthropogenic impact, B1-B5 = habitats with medium anthropogenic impact, can include small waste sites, Cl-C5 = habitats with high anthropogenic impact with large waste sites and/or human settlements.

\begin{tabular}{|c|c|c|c|c|c|c|c|c|}
\hline $\begin{array}{l}\text { Sampling } \\
\text { site }\end{array}$ & Short description & $\begin{array}{l}\text { Sampling } \\
\text { period }\end{array}$ & $\begin{array}{l}\text { Area } \\
\text { (ha) }\end{array}$ & $\begin{array}{l}\text { Housing } \\
\text { estates } \\
(\%)^{1}\end{array}$ & $\begin{array}{l}\text { Villages } \\
(\%)^{2}\end{array}$ & $\begin{array}{l}\text { Open areas with } \\
\text { human } \\
\text { settlements }(\%)^{3}\end{array}$ & $\begin{array}{l}\text { Open } \\
\text { areas } \\
(\%)^{4}\end{array}$ & $\begin{array}{l}\text { Water } \\
(\%)^{5}\end{array}$ \\
\hline A1 & reeds near the wood & Jul12 & 13,81 & & & & & 69.99 \\
\hline $\mathbf{A 2}$ & meadow near the stream & Aug12 & 0,12 & & & & & 0.61 \\
\hline $\mathbf{A 3}$ & $\begin{array}{l}\text { wood, road, small } \\
\text { amount of scattered } \\
\text { waste }\end{array}$ & Sep12 & 0,05 & & & & . & \\
\hline A4 & wood & Oct12 & 0,04 & & & & 0.20 & \\
\hline B1 & $\begin{array}{l}\text { wastesite's edge (near } \\
\text { the wood) }\end{array}$ & Apr-Jul12 & 0,46 & & & 2.33 & & \\
\hline B2 & field and wood edge & Sep12 & 0,05 & & & & 0.25 & \\
\hline B3 & $\begin{array}{l}\text { meadow, small } \\
\text { wastesite, shrubs }\end{array}$ & Jul12 & 0,71 & & & 3.60 & & \\
\hline B4 & wood, road & Aug12 & 0,16 & & & & 0.81 & \\
\hline B5 & $\begin{array}{l}\text { wood, road, meadow, } \\
\text { small wastesite }\end{array}$ & Sep12 & 0,74 & & & & 3.75 & \\
\hline C1 & farm & $\begin{array}{l}\text { Sep12, } \\
\text { Nov12 }\end{array}$ & 0,74 & & 3.75 & & & \\
\hline C2 & wood, pasture & Sep12 & 0,14 & & & & 0.71 & \\
\hline $\mathrm{C3}$ & large wastesite, shrubs & $\begin{array}{l}\text { Oct-Nov11, } \\
\text { Mar-Jul12 }\end{array}$ & 1,72 & & 8.72 & & & \\
\hline $\mathrm{C} 4$ & large wastesite, wood & Aug12 & 0,04 & & & & 0.20 & \\
\hline C5 & $\begin{array}{l}\text { large wastesite, wood, } \\
\text { backyard, shrubs }\end{array}$ & $\begin{array}{l}\text { Oct11, Apr- } \\
\text { Jul12 }\end{array}$ & 0,95 & 4.82 & & & & \\
\hline & & SUM & 19.73 & 4.82 & 12.47 & 5.93 & 6.17 & 70.60 \\
\hline
\end{tabular}




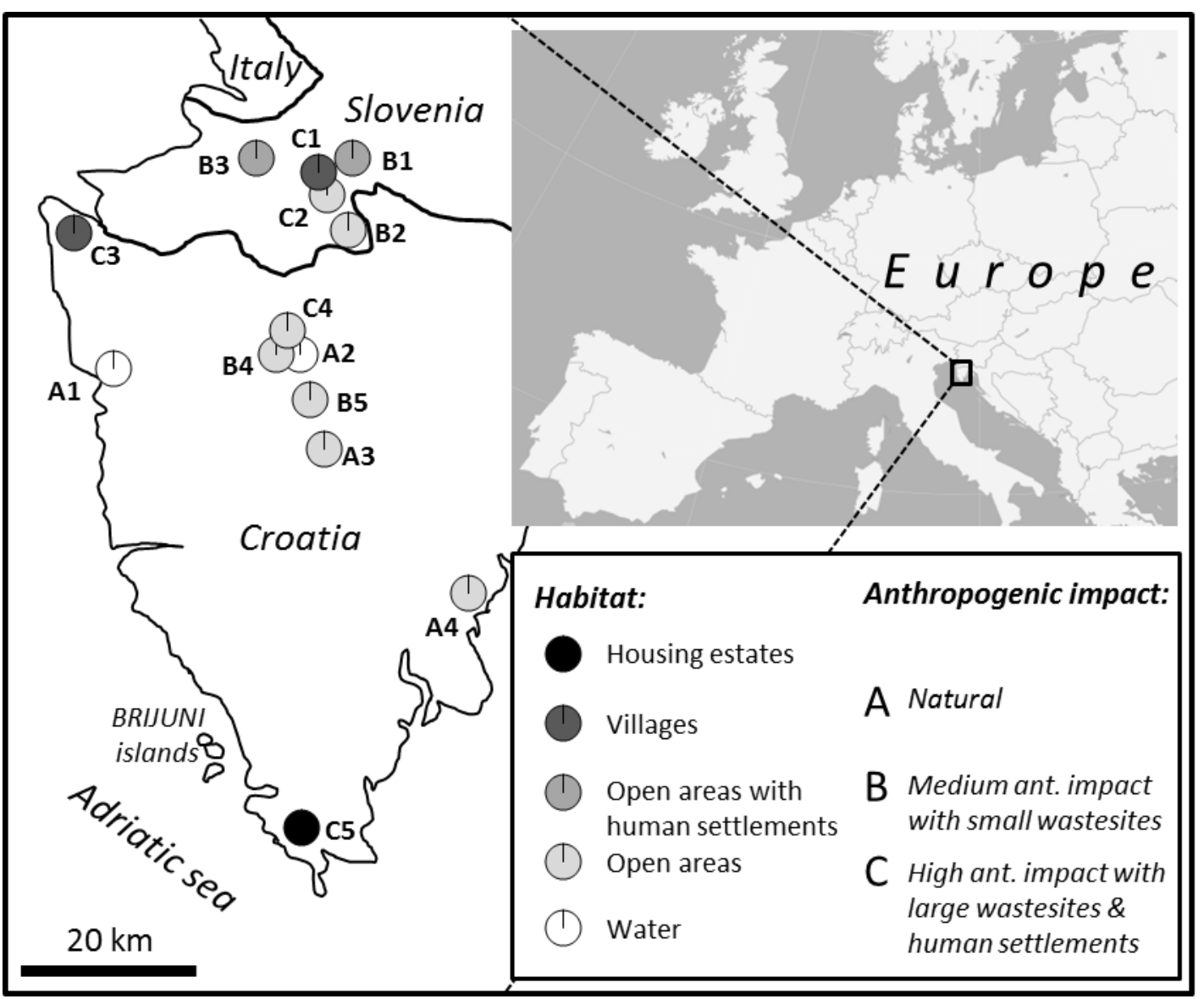

Figure 1. Sampling sites in Istria.

\section{Laboratory work}

Morphometry of key structures, like body length (from the tip of the nose to the anal opening), tail length (from the anal opening to the end of the tail), the length of the rear foot (from the beginning to the end of the finger phalanges without claws,) and the size of the ears (without the final hair) (Kryštufek and Janžekovič, 1999) were measured for species determination purposes. Most juveniles were identified to a species-level based on sequence similarity of mitochondrial cytochrome b gene (cyt b) (Bradley and Baker, 2001).

\section{DNA extraction, PCR amplification, sequencing and sequence analysis}

Tissues from rodent brain and muscle were isolated. DNA extraction was performed using PureLink ${ }^{\circledR}$ Genomic DNA Mini Kit (Invitrogen ${ }^{\mathrm{TM}}$, Life Technologies Corporation, Carlsbad, CA, USA). The cytochrome b gene (cyt b) was amplified with primers, L14727-SP and H15915-SP (Jaarola and Searle, 2002). The alignment yielded the sequence data for partial cyt $\mathrm{b}$ gene sequences of the length between 300 and 500 base pairs (total length in mammals is $1140 \mathrm{bp}$ ). A polymerase chain reaction (PCR) was performed in a total volume of $15 \mu \mathrm{l}$ containing $3 \mu \mathrm{l}$ of DNA extraction, $0.3 \mu \mathrm{m} 10$ pmol forward and reverse primers and $7 \mu \mathrm{l}$ of KAPA HiFi HotStart ReadyMix 2X (Kapa Biosystems, Inc., United States) containing KAPA 
dNTPs, reaction buffer, $\mathrm{Mg}^{2+}$ at a $1 \mathrm{X}$ final conc. of $2.5 \mathrm{mM}$ and KAPA2G fast DNA Polymerase 5 units/ $\mu 1$ and $5.4 \mu 1$ of water.

The PCR cycling conditions included an initial denaturation step at $94^{\circ} \mathrm{C}$ for $3 \mathrm{~min}$, followed by 30 cycles of denaturation $\left(15 \mathrm{~s}\right.$ at $\left.94^{\circ} \mathrm{C}\right)$, primer annealing $\left(30 \mathrm{~s}\right.$ at $\left.48^{\circ} \mathrm{C}\right)$, and extension $\left(1 \mathrm{~min}\right.$ at $\left.72^{\circ} \mathrm{C}\right)$. The final extension at $72^{\circ} \mathrm{C}$ ran for $10 \mathrm{~min}$. The sequencing was performed on an ABI PRISM 3130 Genetic Analyzer using BigDye Terminators (Applied Biosystems, Foster City, CA, USA). The CodonCode Aligner 1.63 (Ewing et al., 1998) was used to align the forward and reverse sequences. The resulting consensus sequences for each individual were aligned using ClustalW 4.0, implemented in the Molecular Evolutionary Genetics Analysis (MEGA) package 5 (Tamura et al., 2011). Species identification was confirmed with Basic Local Alignment Search Tool (BLAST) implemented in National Center for Biotechnology Information (NCBI database). A threshold of $98 \%$ similarity for the same species was defined according to the results of BLASTn search for the sequences.

\section{Data analysis}

For each of the three groups of sites defined by the anthropogenic impact (A, B, C), species composition, abundance and proportions (calculated from abundances) were estimated. Shannon Wiener index $\left(\mathrm{H}^{\prime}=-\Sigma\left(\mathrm{n}_{\mathrm{i}} / \mathrm{n}\right)^{*} \ln \left(\mathrm{n}_{\mathrm{i}} / \mathrm{n}\right)\right.$; where $\mathrm{n}_{\mathrm{i}}=$ number of individuals of a species in a sample $\mathrm{i}$ and $\mathrm{n}=$ number of all individuals in a sample) (Spellerberg and Fedor, 2003) was calculated for each site and the three groups (A, B, C). Average values, standard deviation and range of $\mathrm{H}^{\prime}$ for sites within each of the groups were also calculated. For evaluation of possible interdependence (at $p<0.05$ ) between H' and number of sampled individuals per site, Pearson correlation coefficient (r) was calculated between the two variables. Dominance $\left(\mathrm{D}=\Sigma(\mathrm{ni} / \mathrm{n})^{2}\right)$ and evenness $\left(\mathrm{e}^{\mathrm{H} / \mathrm{S}}, \mathrm{S}=\right.$ no. of sampling sites $)$ of the species per three groups were calculated.

Beta diversity $\left(b_{w}\right)$ and species turnover rates between the three groups of sites were calculated following Whittaker (Koleff et al., 2003): $b_{w}=\left(S / \alpha_{A V G}\right)-1$, where $S$ is total number of species and $\alpha_{\mathrm{AVG}}$ is average number of species.

Species communities were inspected through Unweighted Pair Groups Method (UPGMA), and the clusters of the sites were interpreted according to the level of anthropogenic impact. Distance matrix was computed using Raup Crick index for binary (presence/absence) data (Raup and Crick, 1979) as the sampling effort was uneven. The analysis was conducted in PAST ver. 2.17c, Excel 2010 and SPSS ver. 20.0 .

\section{Results}

In total, three genera and five species of Muridae black rat, domestic mouse, striped field mouse, wood mouse and yellow-necked mouse (Rattus rattus, Mus musculus, Apodemus agrarius, A. sylvaticus and A. flavicollis) were sampled from 14 sampling sites (Figure 2). Most common species was Apodemus agrarius, recorded at 11 sites. At three sampling sites only one species was recorded (M. musculus in an illegal landfill at $\mathrm{C} 4$ and at the farm at the site $\mathrm{C} 1$, and A. agrarius in a wood at the site A4). The largest number of species (all five) were recorded in landfill at $\mathrm{C} 3$ and four species were recorded at landfill C5 ( $R$. rattus, M. musculus, A. agrarius and A. sylvaticus), as well as near the landfills at sites B1 and B3 (M. musculus and all three Apodemus species). 


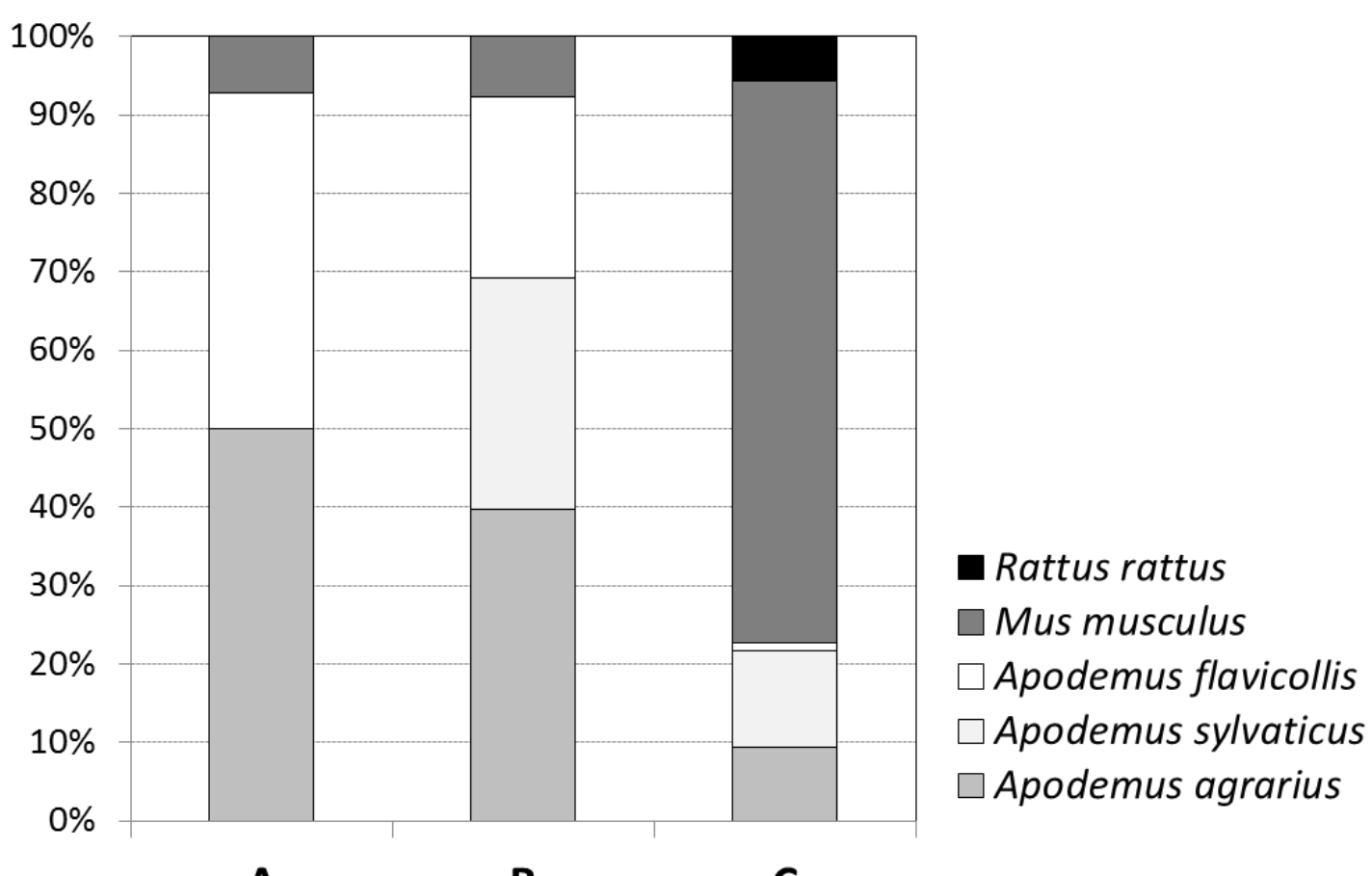

A

B

C

Figure 2. Species composition and relative abundance of five Muridae species at 14 sampling sites in Istria, divided into three groups of habitats according to the human impact ( $A=$ natural habitats with low anthropogenic impact, $B=$ habitats with medium anthropogenic impact, can include small waste sites, $C=$ habitats with high anthropogenic impact with large waste sites and/or human settlements). Numbers of animals $=198:$ Rattus rattus: $A, B=0, C=6$; $M$ us musculus: $A=1, B=6, C=76$; Apodemus flavicollis: $A=6, B=18, C=1$; Apodemus sylvaticus: $A=0 ; B=23, C=13$; Apodemus agrarius: $A=7, B=31, C=10$.

All five species were found in a group of sites with the highest anthropogenic impact (Figure 2), while in groups with medium and lowest impacts, four and three species were recorded, respectively. On average, 2 species $(\mathrm{SD}=1.7)$ were recorded from the sites with highest impact, whereas $3.2(\mathrm{SD}=0.8)$ and 2 species $(\mathrm{SD}=0.8)$ were recorded from sites with medium and low anthropogenic impact, respectively. ShannonWiener species diversity index was highest at sites with medium impact $\left(\mathrm{H}^{\prime}{ }_{\mathrm{B}}=1.26\right.$ $\left[\right.$ mean $_{\text {SITES }} \pm \mathrm{SD}: 0.93 \pm 0.26$; range: $\left.0.50-1.28\right] ; \mathrm{H}_{\mathrm{A}}{ }_{\mathrm{A}}=0.89[0.56 \pm 0.40 ; 0-0.95] ; \mathrm{H}_{\mathrm{C}}$ $=0.92[0.34 \pm 0.58 ; 0-1.18])$, where dominance $(\mathrm{D})$ of the most common species was lowest $\left(D_{B}=0.30 ; D_{A}=0.44 ; D_{C}=54\right)$ and evenness $\left(e^{H / S}\right)$ highest $\left(e^{H / S}{ }_{B}=0.88 ; e^{H / S}{ }_{A}\right.$ $\left.=0.82 ; \mathrm{e}^{\mathrm{H} / \mathrm{S}} \mathrm{C}=0.50\right)$. No significant Pearson correlation $(\mathrm{r}=0.412, \mathrm{p}>0.1)$ was calculated between H' and numbers of caught individuals.

Global Whittaker beta diversity for all 14 sites is 0.25 . The highest species turnover rate is recorded between the group of sites with smallest and largest anthropogenic impact (A-C: 0.25). The turnover rates are approximately half between sites with the medium and highest (B-C: 0.11) and medium and lowest anthropogenic impact (A-B: 0.14).

Cluster analysis of 14 sampling sites revealed two distinct clusters with less than 40 $\%$ of similarity (Figure 3). The first cluster consists of samples from the four largest waste sites and a farm (C1-C5) and the second cluster consists of all other samples. This can be further divided into two sub-clusters. The first sub-cluster consists of 
samples from fields, landfill edges, two small landfills (one in a wooded area and another in a wooded area near the road) (B1-B5). The second sub-cluster consists of samples from two wooded areas, the reeds near the wooded areas, and a meadow with a small stream; A1-A4). The latter sub-clusters join at the $\sim 65 \%$ of similarity rate.

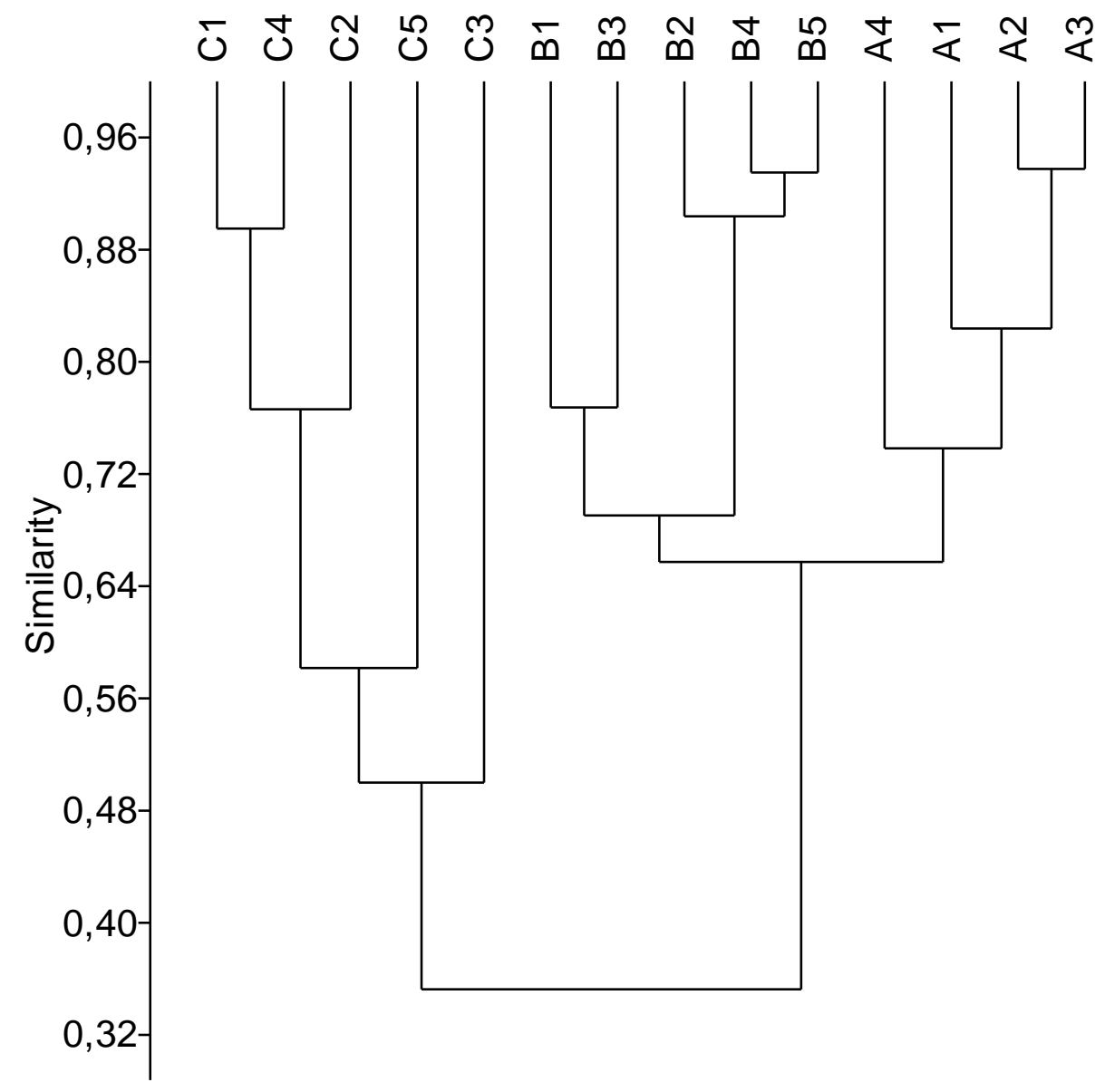

Figure 3. Cluster analysis of species composition of fourteen Muridae samples locations from Istria (UPGMA, Raup-Crick index, binary data on presence and absence was used, coph. corr. $=0.81)$. For explanation of sample abbreviations see Table 1 .

\section{Discussion}

In the present study, the importance of understanding the impacts of urbanization and inadequate waste management on native wildlife and human health is researched. Most of the previous work dealing with urban ecology investigated the effects of urbanisation on habitat quality and other environmental conditions (Grimm et al., 2008; Sims et al., 2007 ) in cities, and how species' ecological and life history traits influence their ability to colonise and survive in urban areas (Croci et al., 2008; Kark et al., 2007; Lim and Sodhi, 2004; Thompson and McCarthy, 2008). The impact of solid waste disposal upon communities of small mammals at the outskirts of the cities and towns has not yet been shown. Cavia et al. (2009) reported that accumulated organic waste and litter provide food and harbourage for rodents. Although we agree that human impact through waste 
disposal almost necessarily changes local species community (Cavia et al., 2009), the consequences may vary between habitats and regions.

While human presence is usually connected with the abundance of food sources for small mammals (Feng and Himsworth, 2014), and thus species number may increase, the structure of community drastically changes. Some rodents however are treated as real commensals as they usually become highly abundant in close proximity of humans (Aplin et al., 2003). Black rat (R. rattus) and house mouse (Mus musculus) are two cases of commensal species that can take the advantage of potentially rich food resources provided by such habitats. Moreover, black rats are so much connected to humans that they are rarely found in the wild (Aplin et al., 2003); with its ability to adapt to a wide array of resources and environments, this species may be the only species within the habitat (Feng and Himsworth, 2014). Although introduced, Rattus rattus is the only Muridae representative on Brijuni archipelago offshore the southern Istria (see Figure 1) (Bužan et al., 2012)(Bužan et al., 2012). Also in our study, black rats were found only in the largest waste sites ( $\geq 1$ ha: C3, C5) with food availability (organic waste) and shelter (infrastructure waste) (Aplin et al., 2003; Wilson and Reeder, 2005).

House mouse, however, is more ubiquitous since they are able to persist entirely in both commensal and non-commensal habitats (Pocock et al., 2004). This is in line with the results of the present study as the house mouse was present in a vast majority of sites, and with 83 trapped animals ( $42 \%$ of total) proved to be the most abundant Muridae species within the area. The species also proved to be commensal as it was most abundant in areas with higher anthropogenic impact. As such, it may also be the most probable candidate for pathogen transmissions. Also two species, Apodemus agrarius and $A$. flavicollis, were found in groups of sites from highest to lowest anthropogenic impact. A. agrarius prefers moist river-valleys and areas with wet and dense vegetation (Zub et al., 2012) and proved to be the dominant species in natural and semi-natural groups of habitats. The forest and dense shrub stands, where there is sporadic occurrence of fallen woody material, however, are preferred by A. flavicollis (Flowerdew, 1985). Although the species was recorded in all three habitat types, its occurrence dropped evidently towards habitats with large waste sites or human settlements where it was trapped only once. Third Apodemus species (A. sylvaticus) was absent from natural habitats with low anthropogenic impact, and almost two times more frequent in habitats with medium anthropogenic impact than in habitats with settlements or large waste sites. Despite the absence from the natural habitats, this species in total was more frequent than A. flavicollis. It is a very adaptable species and inhabits a variety of semi-natural habitats including all types of woodland, moorland, steppe, arid Mediterranean scrublands, and sand dunes (Montgomery, 1989; Vukićević-Radić et al., 2006).

Interestingly, most species were recorded in sites with medium anthropogenic impact, where in our case habitat was changed due to inappropriate waste disposal (average \pm standard deviation: 3.2 species \pm 0.8 ). The mixture of different environments at these sites and potential food resources within the landscape units around these sites allowed the species present in the region to occupy the urban ecosystem (Alard and Poudevigne, 2002). These places can therefore serve as a border habitat for commensal and native species. Moreover, waste sites in this study were recognised as possible refuge for commensal and native rodent species, which enables integration and increases possibilities of spreading of rodent-related diseases. Hence agriculture and 
urbanisation with the connected waste disposal activities will put humans at risk of contracting a series of rodent-related diseases (Udonsi, 1989). Moreover, improper waste management is driving the native species to local extinctions and replacing them with invasive commensal rodents, thereby reducing biodiversity and ecosystem health (Joyce et al., 2000).

As a quantifiable impact upon changes in rodent communities at our study area, we can stress that while antibodies for Lymphocytic Choriomeningitis Virus (LCMV) was present in $24.1 \%$ of animals from the entire area $(\mathrm{N}=83$ individuals, see Buzan et al. 2012; Buzan, unpublished), seroprevalence was always much lower at the reference sites (Croatia: $6.7 \%$; Slovenia: $9.1 \%$ ) than at the waste sites (Croatia: $39.0 \%$; Slovenia: $33.3 \%)$. Moreover, also the rate of parasitism ( $\mathrm{N}=103$ individuals) was more pronounced at waste sites $(56 \%)$ and less at the reference sites (44\%). Among 26 documented ecto- and endoparasites, eight could be potentially harmful also for people (Bužan et al., 2012). Increased rates of both at the waste sites can influence not only to the people but also to some predator species (e.g. foxes, common buzzards, cats; see Hanski et al. 1991 for the complete list). Generalist predators can either adjust their feeding choice to the available rodent species or switch to other available prey. Although in some cases generalist predators can even profit from the increased density of small mammals at the waste sites, they are also more exposed to the risk of transferring some parasites and diseases. On the other hand specialist small rodent predators (e.g. small mustelids; see Hanski et al. 1991) may be crucially influenced by the community change despite higher densities of small mammals as they are even more exposed to the possibility of parasite and disease transfers. Overall, our study results indicate that multiple features of waste sites influence infection risk and parasitism of host and suggest that synergism between traits can have important effects on predators and people.

In the majority of studies the number of rodent-borne diseases relates to the rodent population densities (Escutenaire et al., 2000; Olsson et al., 2002). Higher densities of rodents increase the likelihood of contact between rodents and man, which leads to a higher likelihood of disease transmission (Davis et al., 2004; Niklasson et al., 1995). Transmission can occur by direct contact, by bites, through the pathogen contamination of water or food sources (Slifko et al., 2000), or via arthropod vectors (Lindgren and Gustafson, 2001). Introducing commensal rodents to waste sites enables them to colonize the regions that are otherwise inhabited by native rodents, and gives them additional abilities for transmission of infectious agents from commensal rodents to native ones. Such contact favours the transmission of parasites by direct contact or via oral-faecal routes (Slifko et al., 2000). The monitoring of Lymphocytic choriomeningitis virus, flavivirus, Leishmania sp. and taxoplasmosis showed increased seroprevalence infections in rodents sampled at illegal waste sites (Bužan et al., 2012; Ivović et al., 2015).

Understanding rodent ecology and gene flow, including movement of commensal rodents with respect to human expansion in urban landscapes, is critical for understanding the dynamics of rodent-borne pathogens and is valuable for mitigating human disease outbreaks (Mills et al., 1999). 


\section{Conclusions}

The present study shows that illegal waste sites can present a potential place for spreading commensal rodents to the natural environment. These consequences of urbanization represent threats to human health due to spreading rodent-related diseases but will also drive the native species to local extinction and replacing them with nonnative species. The ecological and economic damage caused by illegal waste sites is well known to the scientific community, but there is still a lack of awareness of these problems in landowners and the population in general. Inevitabelly we showed that not only the waste sites impact upon small rodents' community change, but also increase the risk of native species being overcompeted by the invasive small rodents that further influence on the entire ecosystem by exposing the native species (including their predators) and people to more likely get infected by some zoonoses or parasites.

Acknowledgements. The authors would like to thank Amy Simmons (University of Primorska) who kindly reviewed the manuscript and improved English. We also thank to our collegues from Department of Biodiversity and Institute for Biodiversity studies at of University of Primorska Tilen Genov, Vladimir Ivović, Peter Maričič, Katja Kalan, Toni Koren, Felicita Urzi, Peter Glasnović and our students from the Faculty of Mathematics, Natural Sciences and Information Technologie: Domen Trkov, Sandra Hasić, Mitja Črne, Barbara Horvath, Tjaša Zagoršek in Urban Kunej for help on the field and laboratory work. This study was founded by DIVA project (co- financed within the IPA CBC Operational Programme SLO-HR 2007-2013). The support of COST Action TD1303 “European Network for Neglected Vectors and Vector-Borne Infections (EURNEGVEC)'” is also acknowledged.

\section{REFERENCES}

[1] Alard, D., Poudevigne, I. (2002): Biodiversity in changing landscapes: from species or patch assemblages to system organisation. - In: Leuven, R.S.E.W., Poudevigne, I., Teuw, R.M. (Eds.) Application of Geographic Information Systems and Remote Sensing in River Studies. Backhuys, Leiden, pp. 9-24.

[2] Aplin, K.P., Chesser, T., ten Have, J. (2003): Evolutionary biology of the genus Rattus: profile of an archetypal rodent pest. - In: Singleton, G.R., Hinds, L.A., Krebs, C.J., Spratt, D.M. (Eds.), Rats, Mice and People: Rodent Biology and Management. ACIAR, Canberra, pp. 487-498.

[3] Aronson, M.F.J., La Sorte, F.A., Nilon, C.H., Katti, M., Goddard, M. a, Lepczyk, C. a, Warren, P.S., Williams, N.S.G., Cilliers, S., Clarkson, B., Dobbs, C., Dolan, R., Hedblom, M., Klotz, S., Kooijmans, J.L., Kuhn, I., MacGregor-Fors, I., McDonnell, M., Mortberg, U., Pysek, P., Siebert, S., Sushinsky, J., Werner, P., Winter, M. (2014): A global analysis of the impacts of urbanization on bird and plant diversity reveals key anthropogenic drivers. - Proc. R. Soc. B Biol. Sci. 281: 20133330-20133330.

[4] Ashworth, D.C., Elliott, P., Toledano, M.B. (2014): Waste incineration and adverse birth and neonatal outcomes: a systematic review. - Environ. Int. 69: 120-132.

[5] Baibergenova, A., Kudyakov, R., Zdeb, M., Carpenter, D.O. (2003): Low Birth Weight and Residential Proximity to PCB-Contaminated Waste Sites. - Environ. Health Perspect. 111: 1352-1357.

[6] Ballantyne, M., Pickering, C.M. (2015): Recreational trails as a source of negative impacts on the persistence of keystone species and facilitation. - J. Environ. Manage. 159: $48-57$.

[7] Battersby, J.E., Greenwood, J.J.D. (2004): Monitoring terrestrial mammals in the UK: past, present and future, using lessons from the bird world. - Mamm. Rev. 34: 3-29.

[8] Battersby, S.A. (2004): Public health policy - can there be an economic imperative? An 
examination of one such issue. - J. Environ. Heal. Res. 3: 19-29.

[9] Bohn, U., Gollub, G., Hettwer, C., Neuhäuslová, Z., Raus, T., Schlüter, H., Weber, H., Hennekens, S. (2004): Map of the Natural Vegetation of Europe. Scale 1:2 500 000. Bundesamt für Naturschutz, Bonn: 153.

[10] Bradley, C.A., Altizer, S. (2007): Urbanization and the ecology of wildlife diseases. Trends Ecol. Evol. 22: 95-102.

[11] Bradley, R.D., Baker, R.J. (2001): A Test of the Genetic Species Concept: Cytochrome-b Sequences and Mammals. - J. Mammal. 82: 960-973.

[12] Bužan, E., Duh, D., Fišer Pečnikar, Ž., Glasnović, P., Ivović, V., Kalan, K., Maričič, P., Zupan, S. (2012): Škodljivi vplivi divjih odlagališč na biodiverziteto in zdravje ljudi = Utjecaj divljih odlagališta na biološku raznolikost i ljudsko zdravlje. - Univerzitetna založba Annales, Koper: Univerza na Primorskem, Znanstveno-raziskovalno središče, Inštitut za biodiverzitetne študije.

[13] Cavia, R., Cueto, G.R., Suárez, O.V. (2009): Changes in rodent communities according to the landscape structure in an urban ecosystem. - Landsc. Urban Plan. 90: 11-19.

[14] Cori, B. (1999): Spatial dynamics of Mediterranean coastal regions. - J. Coast. Conserv. 5: $105-112$.

[15] Council Directive 1999/31/EC on the landfill of waste. (1999): Off. J. Eur. Communities.

[16] Croci, S., Buttet, A., Clergeau, P. (2008): Does Urbanization Filter Birds on the Basis of Their Biological Traits? - Condor 110: 223-240.

[17] Dall, S.R.X., Cuthill, I.C. (1997): The Information Costs of Generalism. - Oikos 80: 197.

[18] Davis, S., Begon, M., Bruyn, L. De, Ageyev, V.S., Klassovskiy, N.L., Pole, S.B., Viljugrein, H., Stenseth, N.C., Leirs, H., De Bruyn, L., Ageyev, V.S., Klassovskiy, N.L., Pole, S.B., Viljugrein, H., Stenseth, N.C., Leirs, H. (2004): Predictive thresholds for plague in Kazakhstan. - Science 304: 736-8.

[19] Desjeux, P. (2001): The increase in risk factors for leishmaniasis worldwide. - Trans. R. Soc. Trop. Med. Hyg. 95: 239-243.

[20] Desrochers, R.E., Kerr, J.T., Currie, D.J. (2011): How, and how much, natural cover loss increases species richness. - Glob. Ecol. Biogeogr. 20: 857-867.

[21] Diletti, G., Ceci, R., Conte, A., Benedictis, A., Migliorati, G., Scortichini, G. (2008): Milk Contamination from Dioxins in Italy: Source Identification and Intervention Strategies. - In: Mehmeti, E., Koumanova, B. (Eds.) The Fate of Persistent Organic Pollutants in the Environment. - Springer Netherlands, Dordrecht, pp. 301-314.

[22] Drummond, D.C. (2001): Rodents and biodeterioration. - Int. Biodeterior. Biodegradation 48: $105-111$.

[23] Ellenberg, H., Leuschner, C. (2010): Vegetation Mitteleuropas mit den Alpen. - In ökologischer, dynamischer und historischer Sicht, 6., völlig überarb. Aufl. ed. UTB, Stuttgart

[24] Elliott, P., Briggs, D., Morris, S., de Hoogh, C., Hurt, C., Kold Jensen, T., Maitland, I., Richardson, S., Wakefield, J., Jarup, L. (2001): Risk of adverse birth outcomes in populations living near landfill sites. - BMJ 323: 363-368.

[25] Escutenaire, S., Chalon, P., Verhagen, R., Heyman, P., Thomas, I., Karelle-Bui, L., Avsic-Zupanc, T., Lundkvist, Å., Plyusnin, a., Pastoret, P.P. (2000): Spatial and temporal dynamics of Puumala hantavirus infection in red bank vole (Clethrionomys glareolus) populations in Belgium. - Virus Res. 67: 91-107.

[26] Ettler, V., Mihaljevič, M., Matura, M., Skalová, M., Sebek, O., Bezdička, P. (2008): Temporal variation of trace elements in waters polluted by municipal solid waste landfill leachate. Bull. Environ. - Contam. Toxicol. 80: 274-9.

[27] Ewing, B., Hillier, L., Wendl, M.C., Green, P. (1998): Base-Calling of Automated Sequencer Traces Using Phred. I. Accuracy Assessment. - Genome Res. 8: 175-185.

[28] Feng, A.Y.T., Himsworth, C.G. (2014): The secret life of the city rat: a review of the ecology of urban Norway and black rats (Rattus norvegicus and Rattus rattus). - Urban Ecosyst. 17: 149-162. 
[29] Flowerdew, J.R. (1985): The population dynamics of wood miceand yellow-necked mice. - Symposia of the Zoological Society of London, pp. 315-338.

[30] Giusti, L. (2009): A review of waste management practices and their impact on human health. - Waste Manag. 29: 2227-2239.

[31] Grimm, N.B., Faeth, S.H., Golubiewski, N.E., Redman, C.L., Wu, J., Bai, X., Briggs, J.M. (2008): Global change and the ecology of cities. - Science 319: 756-760.

[32] Gržinić, J. (2010): Sustainable development of highly touristic region of Istria. - Manag. Mark. 8: 57-65.

[33] Ivović, V., Kalan, K., Zupan, S., Bužan, E. (2015): Illegal Waste Sites As A Potential Micro Foci Of Mediterranean Leishmaniasis: First Records Of Phlebotomine Sand Flies (Diptera: Psychodidae) From Slovenia. - Acta Vet. Brno. 65: 348-357.

[34] Jaarola, M., Searle, J.B. (2002): Phylogeography of field voles (Microtus agrestis) in Eurasia inferred from mitochondrial DNA sequences. - Mol. Ecol. 11: 2613-2621.

[35] Joyce, L.A., Mitchell, J.E., Loftin, S.R. (2000). Applicability of Montreal Process Criterion 3 - maintenance of ecosystem health - to rangelands. - Int. J. Sustain. Dev. World Ecol. 7: 107-127.

[36] Kaligarič, M., Culiberg, M., Kramberger, B. (2006): Recent vegetation history of the North Adriatic grasslands: Expansion and decay of an anthropogenic habitat. - Folia Geobot. 41:241-258.

[37] Kark, S., Iwaniuk, A., Schalimtzek, A., Banker, E. (2007): Living in the city: can anyone become an "urban exploiter"? - J. Biogeogr. 34: 638-651.

[38] Klimesová, J., Klimeš, L. (2007): Bud banks and their role in vegetative regeneration - A literature review and proposal for simple classification and assessment. - Perspect. Plant Ecol. Evol. Syst. 8: 115-129.

[39] Kokalj, Ž., Oštir, K. (2005): Ugotavljanje pokrovnosti iz satelitskih posnetkov. - Geogr. Obz. 52:12-18.

[40] Koleff, P., Gaston, K.J., Lennon, J.J. (2003): Measuring beta diversity for presenceabsence data. - J. Anim. Ecol. 72: 367-382.

[41] Kotovicova, J., Toman, F., Vaverkova, M., Stejskal, B. (2011): Evaluation of Waste Landfills' Impact on the Environment Using Bioindicators. - Polish J. of Environ. Stud. 20: 371-377.

[42] Kramer, M.S. (1987): Determinants of low birth weight: methodological assessment and meta-analysis. - Bulletin of the World Health Organization 65: 663-737.

[43] Krauss, J., Klein, A.M., Steffan-Dewenter, I., Tscharntke, T. (2004): Effects of habitat area, isolation, and landscape diversity on plant species richness of calcareous grasslands. - Biodivers. Conserv. 13: 1427-1439.

[44] Krebs, N. (1907): Die Halbinsel Istrien Landeskundliche Studie. Geogr. Abhandl. hg. v. A. Penck IXj2. Leipzig.

[45] Kryštufek, B., Janžekovič, F. (1999): Ključ za določanje vretenčarjev Slovenije, First. ed. - DZS, Ljubljana: 544.

[46] Lim, H.C., Sodhi, N.S. (2004): Responses of avian guilds to urbanisation in a tropical city. - Landsc. Urban Plan. 66: 199-215.

[47] Lindgren, E., Gustafson, R. (2001): Tick-borne encephalitis in Sweden and climate change. - Lancet 358: 16-18.

[48] Macpherson, D., Macpherson J.L., Morris, P. (2011) Rural roads as barriers to the movements of small mammals. - Appl. Ecol. Environ. Res. 9: 167-180.

[49] Mattiello, A., Chiodini, P., Bianco, E., Forgione, N., Flammia, I., Gallo, C., Pizzuti, R., Panico, S. (2013): Health effects associated with the disposal of solid waste in landfills and incinerators in populations living in surrounding areas: A systematic review. - Int. J. Public Health 58: 725-735.

[50] Mazzanti, M., Zoboli, R. (2008): Waste generation, waste disposal and policy effectiveness. - Resour. Conserv. Recycl. 52: 1221-1234.

[51] McDonnell, M.J., Pickett, S.T. (1990): Ecosystem structure and function along gradients: 
an unexploited urban-rural opportunity for ecology. - Ecology 71: 1232-1237.

[52] McDonnell, M.J., Pickett, S.T.A., Groffman, P., Bohlen, P., Pouyat, R. V., Zipperer, W.C., Parmelee, R.W., Carreiro, M.M., Medley, K. (1997): Ecosystem processes along an urban-to-rural gradient. - Urban Ecosyst. 1: 21-36.

[53] McKinney, M.L. (2002): Urbanization, Biodiversity, and Conservation. - Bioscience 52: 883-890.

[54] McKinney, M.L. (2006): Urbanization as a major cause of biotic homogenization. - Biol. Conserv. 127: 247-260.

[55] McKinney, M.L. (2008): Effects of urbanization on species richness: A review of plants and animals. - Urban Ecosyst. 11: 161-176.

[56] Melles, S., Glenn, S.M.., Martin, K. (2003): Urban Bird Diversity and Landscape Complexity: Species-Environment Associations Along a Multiscale Habitat Gradient. Conserv. Ecol. 7: 22.

[57] Mills, J., Ksiazek, T.G., Peters, C.J., Childs, J.E. (1999): Long-Term Studies of Hantavirus Reservoir Populations in the Southwestern United States: A Synthesis. Emerg. Infect. Dis. 5: 135-142.

[58] Minichilli, F., Bartolacci, S., Buiatti, E., Pallante, V., Scala, D., Bianchi, F. (2005): A study on mortality around six municipal solid waste landfills in Tuscany Region. Epidemiol. Prev. 29: 53-56.

[59] Montgomery, W.I. (1989): Population Regulation in the Wood Mouse, Apodemus sylvaticus. II. Density Dependence in Spatial Distribution and Reproduction. - J. Anim. Ecol. 58: 477-494.

[60] Morello, J., Buzai, G.D., Baxendale, C.A., Rodríguez, A.F., Matteucci, D.S., Godagnone, R.E., Casas, R.R. (2000): Urbanization and the consumption of fertile land and other ecological changes: the case of Buenos Aires. - Environ. Urban. 12: 119-131.

[61] Niklasson, B., Hornfeldt, B., Lundkvist, A., Bjorsten, S., Leduc, J. (1995): Temporal dynamics of Puumala virus antibody prevalence in voles and of nephropathia epidemica incidence in humans. - Am. J. Trop. Med. Hyg. 53: 134-140.

[62] Olsson, G.E., White, N., Ahlm, C., Elgh, F., Verlemyr, A.-C., Juto, P., Palo, R.T. (2002): Demographic factors associated with hantavirus infection in bank voles - Clethrionomys glareolus. - Emerg. Infect. Dis. 8: 924-929.

[63] Pocock, S.J., Collier, T.J., Dandreo, K.J., De Stavola, B.L., Goldman, M.B., Kalish, L.A., Kasten, L.E., McCormack, V.A. (2004): Issues in the reporting of epidemiological studies: a survey of recent practice. - BMJ 329: 883-888.

[64] Porta, D., Milani, S., Lazzarino, A.I., Perucci, C.A., Forastiere, F. (2009): Systematic review of epidemiological studies on health effects associated with management of solid waste. - Environ. Heal. 8: 60.

[65] Power, A.G. (2010): Ecosystem services and agriculture: tradeoffs and synergies. Philos. Trans. R. Soc. B Biol. Sci. 365: 2959-2971.

[66] Raup, D.M., Crick, R.E. (1979): Measurement of Faunal Similarity in Paleontology. - J. Paleontol. 53: 1213-1227.

[67] Reddy, K.R., Chirakkara, R. A. (2013): Green and Sustainable Remedial Strategy for Contaminated Site: Case Study. - Geotech. Geol. Eng. 31: 1653-1661.

[68] Rodríguez, G., Alegre, F.J., Martínez, G. (2007): The contribution of environmental management systems to the management of construction and demolition waste: The case of the Autonomous Community of Madrid (Spain). - Resour. Conserv. Recycl. 50: 334349.

[69] Rusterholz, H.-P., Wirz, D., Baur, B. (2012): Garden waste deposits as a source for nonnative plants in mixed deciduous forests. - Appl. Veg. Sci. 15: 329-337.

[70] Savard, J.-P.L., Clergeau, P., Mennechez, G. (2000): Biodiversity concepts and urban ecosystems. Landsc. - Urban Plan. 48: 131-142.

[71] Semenza, J.C., Menne, B. (2009): Climate change and infectious diseases in Europe. Lancet Infect. Dis. 9: 365-375. 
[72] Sims, V., Evans, K.L., Newson, S.E., Tratalos, J.A., Gaston, K.J. (2007): Avian assemblage structure and domestic cat densities in urban environments. - Divers. Distrib. 14: 387-399.

[73] Slifko, T.R., Smith, H. V., Rose, J.B. (2000): Emerging parasite zoonoses associated with water and food. - Int. J. Parasitol. 30: 1379-1393.

[74] Smart, S.M., Thompson, K., Marrs, R.H., Le Duc, M.G., Maskell, L.C., Firbank, L.G. (2006): Biotic homogenization and changes in species diversity across human-modified ecosystems. - Proc. R. Soc. B Biol. Sci. 273: 2659-2665.

[75] Sombke, B.A., Schlegel, M. (2007): Orthoptera and Mantodea of Istria and the Croatian Island Šipan. - Rostocker Meeresbiologische Beiträge 18: 131-137.

[76] Sorsa, M., Wilbourn, J., Vainio, H. (1992): Human cytogenetic damage as a predictor of cancer risk. - IARC Sci. Publ. 543-554.

[77] Spellerberg, I.F., Fedor, P.J. (2003): A tribute to Claude Shannon (1916-2001) and a plea for more rigorous use of species richness, species diversity and the "Shannon-Wiener" Index. - Glob. Ecol. Biogeogr. 12: 177-179.

[78] Sullivan, F.M. (1993): Impact of the environment on reproduction from conception to parturition. Environ. - Health Perspect. 101: 13-18.

[79] Tamura, K., Peterson, D., Peterson, N., Stecher, G., Nei, M., Kumar, S. (2011): MEGA5: Molecular evolutionary genetics analysis using maximum likelihood, evolutioanry distance, and maximum parsimony methods. - Mol. Biol. Evol. 28: 2731-2739.

[80] Thompson, K., McCarthy, M. A. (2008): Traits of British alien and native urban plants. J. Ecol. 96: 853-859.

[81] Udonsi, J.K. (1989): Helminth parasites of wild populations of the black rat, Rattus rattus (L.), from urban, rural residential and other ecological areas of Nigeria. - J. Acta Parasitol. Pol. 34: 107-116.

[82] UNDESA, Population Division. World Urbanisation Prospects: The 2009 Revision. (2010): United Nations Department of Economic and Social Affairs, New York.

[83] UNEP/MAP/BP/RAC. A sustainable future for the Mediterranean, 2005. - In: United Nations Environment Programme, Vallbone.

[84] UNEP/MAP: State of the Mediterranean Marine and Coastal Environment, 2012. - In: UNEP/MAP. Barcelona Convention, Athens.

[85] Vrijheid, M. (2000): Health Effects of Residence Near Hazardous Waste Landfill Sites: A Review of Epidemiologic Literature Epidemiologic Studies on Health Effects of Landfill Sites. - Environ. Health Perspect. 108: 101-112.

[86] Vukićević-Radić, O., Matić, R., Kataranovski, D., Stamenković, S. (2006): Spatial organization and home range of Apodemus flavicollis and A. agrarius on Mt. Avala, Serbia. - Acta Zool. Acad. Sci. Hungaricae 52: 81-96.

[87] Wilson, D.E., Reeder, D.A. (2005): Mammal species of the world: a taxonomic and geographic reference. Johns Hopkins Univ. Press. Balt.

[88] Zub, K., Jędrzejewska, B., Jędrzejewski, W., Bartoń, K. A. (2012): Cyclic voles and shrews and non-cyclic mice in a marginal grassland within European temperate forest. Acta Theriol. (Warsz). 57: 205-216. 